\title{
Cells which contain S-100 protein in Hodgkin's disease: a quantitative study
}

\author{
G SANGSTER, † J CROCKER, ${ }^{*}$ RACHEL JENKINS, ${ }^{*}$ MJ LEYLAND $\dagger$ \\ From the Departments of *Histopathology and $\uparrow$ Haematology, East Birmingham Hospital, Birmingham
}

SUMMARY Paraffin sections from a series of 50 lymph nodes affected by Hodgkin's disease were examined by means of the unlabelled primary antibody peroxidase-antiperoxidase method to detect those cells which contained S-100 protein. In addition, 15 lymph nodes showing reactive follicular hyperplasia were studied. A simple enumeration procedure (eyepiece graticule) was used to count the number of such cells in 20 standard $25 \times$ microscope fields. In the specimens of nodular sclerosing Hodgkin's disease many cells positive for S-100 protein were present, in contrast to the other Rye subtypes, which showed a relative paucity. By comparison, the lymph nodes showing reactive follicular hyperplasia contained a similar number of cells containing $\mathrm{S}-100$ to those seen in the nodular sclerosing lymph nodes affected by Hodgkin's disease.

The interdigitating reticulum cell is found in the interfollicular areas of normal thymus dependent lymph nodes and those showing reactive follicular hyperplasia. In these sites the interdigitating reticulum cells are believed to have an important role in the presentation of antigen to $T$ lymphocytes, a process which may be implicated in the pathogenesis of Hodgkin's disease and other neoplasms.

The recent findings of S-100 protein in both the interdigitating reticulum cells of lymphoid tissues ${ }^{1}$ and the Langerhans' cells of certain epithelia ${ }^{2}$ have facilitated the study of these cells in paraffin sections of tissues by immunohistochemical techniques. These techniques have advantages over certain other available methods, which may require either frozen sections or ultrastructural methods.

The Rye classification of Hodgkin's disease subjectively relates the content of histiocytic reticulum cells, Hodgkin cells, and Reed-Sternberg cells to the proportion of lymphocytes in the affected tissue. It is becoming evident from recent quantitative studies, however, that there are unexpected and important differences in the distribution of various cell types. Such studies have so far concentrated on cells positive for $\alpha$-naphthyl acetate esterase, ${ }^{3}$ eosinophil polymorphs, ${ }^{4}$ and mast cells. ${ }^{5}$

The functions of the polymorphic cellular content of Hodgkin's disease are not fully understood, but a study of interdigitating reticulum cells, which seem to link the activities of the mononuclear phagocytic

Accepted for publication 8 May 1985 system with lymphoid cells, may throw light on the basis of the classification of the disease. Accordingly, a quantitative study of cells containing S-100 protein in Hodgkin's disease (which should be largely interdigitating reticulum cells) was undertaken.

\section{Material and methods}

TISSUES EXAMINED

Fifty lymph nodes from 50 patients were examined. Of these, 12 were of the lymphocyte predominant type, 19 showed nodular sclerosis, 14 were of the mixed cellularity subtype, and the remaining five showed depletion of lymphocytes. An additional 15 lymph nodes with reactive follicular hyperplasia were also studied.

\section{FIXATION AND STAINING}

All specimens were fixed for 24 to 48 hours in $10 \%$ formol-saline at room temperature and then processed routinely to paraffin wax. Sections were cut at a thickness of $3 \mu \mathrm{m}$ and taken to Tris-saline buffer (pH 7.6). The sections were then treated with $3 \%$ hydrogen peroxide in methanol for 15 minutes at room temperature to block endogenous peroxidase, followed by a wash in Tris-saline buffer ( $\mathrm{pH} \mathrm{7.6)}$. Background staining was minimised by incubation with normal (non-immune) swine serum, diluted 1/5 for 20 minutes. A standard primary antibody peroxidase-antiperoxidase reaction was then applied, using rabbit antibovine S-100 protein antiserum (Mercia Brocades Ltd, Weybridge, Surrey, 
England) at a dilution of $1 / 25-1 / 50$, followed by swine antirabbit immunoglobulin (at 1/50), then rabbit primary antibody peroxidase-antiperoxidase complex (at $1 / 50)$. The reaction was developed by a standard 3,3' diaminobenzidine procedure and the sections were then counterstained with Mayer's haemalum, dehydrated, cleared, and mounted in synthetic medium. The usual controls, as described previously, ${ }^{6}$ were performed.

\section{PROCEDURE FOR COUNTING}

The cells positive for S-100 were counted per 20 standard fields, using a $25 \times$ objective lens and $10 \times$ eyepiece with a standard eyepiece grid graticule; fields were selected at random. (Preliminary experiments using a Digiplan (Kontron) interactive image analyser and projection microscope had proved no less cumbersome than this technique.)

\section{Results}

In the specimens with Hodgkin's disease cells corresponding in site and nuclear appearance to interdigitating reticulum cells stained intensely for $S-100$ protein. Weak staining was occasionally observed in a very small number of recognisable histiocytic reticulum cells in some follicles of lymph nodes showing reactive follicular hyperplasia; the intensity of staining was such that differentiation between the two (presumed) cell types was straightforward. Other cell types showed no positive staining. In the specimens of reactive follicular hyperplasia the cells strongly positive for $\mathrm{S}-100$ protein were observed in the interfollicular areas but were absent from follicles and sinuses.

As for the specimens with Hodgkin's disease, in the predominant lymphocyte subtype, cells positive for S-100 protein accounted for 7-76 cells $/ 20$ fields (pooled mean $=39 \cdot 3$ ); in the group with nodular sclerosis, $181-512$ cells (pooled mean $=320 \cdot 3$ ); for the specimens showing mixed cellularity Hodgkin's disease, 3-86 cells (pooled mean $=35$ ); and for those with depletion of lymphocytes, $2-13$ cells $/ 20$ fields (pooled mean $=8.6$ ) (Fig. 1). The specimens of reactive follicular hyperplasia contained from 191 to 397 cells positive for S-100 protein in the same area (pooled mean 249.6 cells). The Table shows the statistical differences between the pooled data for each Rye subtype of Hodgkin's disease and for the specimens of reactive follicular hyperplasia (using Student's $t$ test). Figs. 2 and 3 depict cells positive for S-100 in typical sections of Hodgkin's disease.

Although these cells were occasionally observed adjacent to Reed-Sternberg cells, no constant spatial relationship was observed between these two types of cell.

\section{Discussion}

The presence of interdigitating reticulum cells may be shown by various means in sections of tissue. Techniques include the examination of tissues using thin sections, ${ }^{7}$ where the interdigitating reticulum cell is said to possess a characteristic nuclear profile. The cells also show weak staining for non-specific esterases and acid phosphatase. ${ }^{8}$ Interdigitating reticulum cells also bear, for example, immuno- $?$ cytochemically visible Ia antigen but are probably Fc $\mu$ and C3b receptor negative. ${ }^{9}$ Recently, S-100 protein, an acidic protein that binds calcium, which was first identified in neural ${ }^{10}$ and melanocytic cells, has been shown in the interdigitating reticulum cells of peripheral lymphoid tissue," $"$ human thymic medulla, and in thymomas, ${ }^{12}$ as well as Langerhans cells. $^{2}$

\section{Lymphocyte predominant

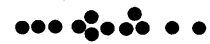

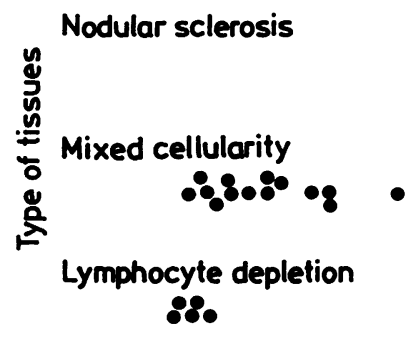

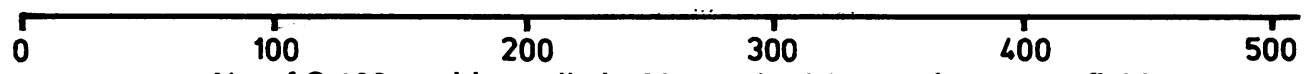

No of S-100-positive cells in 20 standard $25 \times$ microscope fields

Fig. 1 Cells positive for $S-100$ in subtypes of Hodgkin's disease. 
Significance of differences ( $p$ values) between Rye subtypes of specimens from patients with Hodgkin's disease and reactive follicular hyperplasia

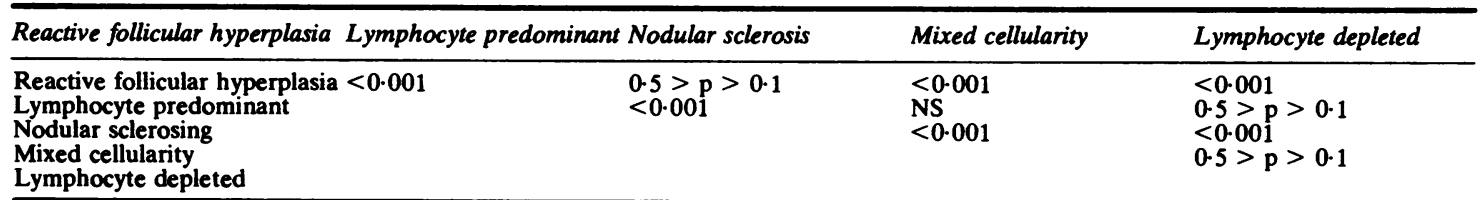

NS = not significant.

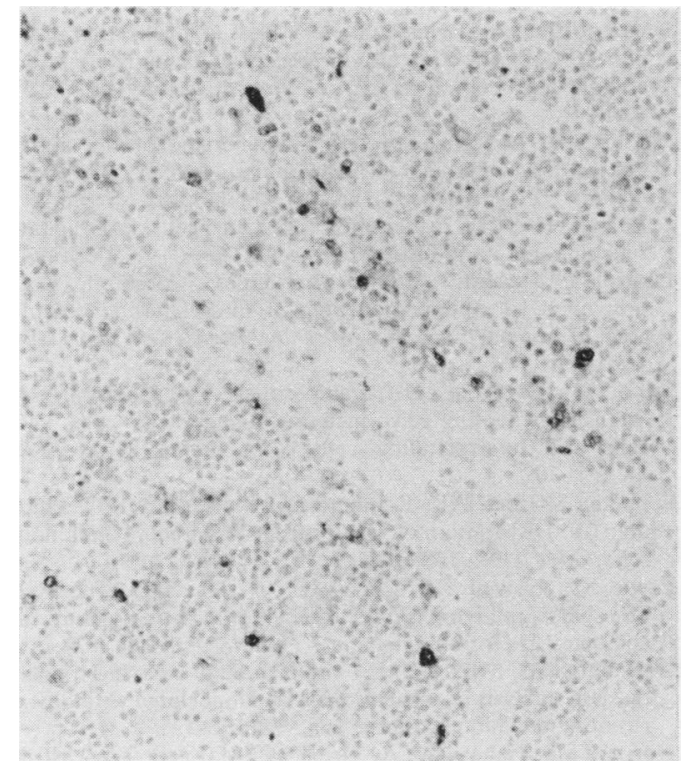

Fig. 2 Nodular sclerosing Hodgkin's disease showing many positive interdigitating reticulum cells. Primary antibody peroxidase-antiperoxidase method for $S-100$ protein. Haemalum counterstain. $\times 250$.

The interdigitating reticulum cell seems to be closely related to the Langerhans' cell and they may both be derived from the veiled cell found in the dermis, which itself arises from the peripheral blood monocyte originating in bone marrow. It is suggested that both the interdigitating reticulum cells and the Langerhans' cell function in the presentation of antigen, the production of lymphokine, and the provision of a microenvironment for $\mathrm{T}$ lymphocytes. ${ }^{13}$ In human lymph nodes the interdigitating reticulum cell is closely associated with $\mathrm{T}$ lymphocytes. ${ }^{14}$

The role of lymphocytes associated with ReedSternberg cells in Hodgkin's tissue remains obscure $^{15}$ but there would seem to be a relation between a predominance of lymphocytes in affected tissues and the prognosis of the disease as shown by the different clinical courses of the Rye subtypes of Hodgkin's disease. Studies of lymphocyte populations in cell suspensions of Hodgkin's tissue ${ }^{1617}$ have

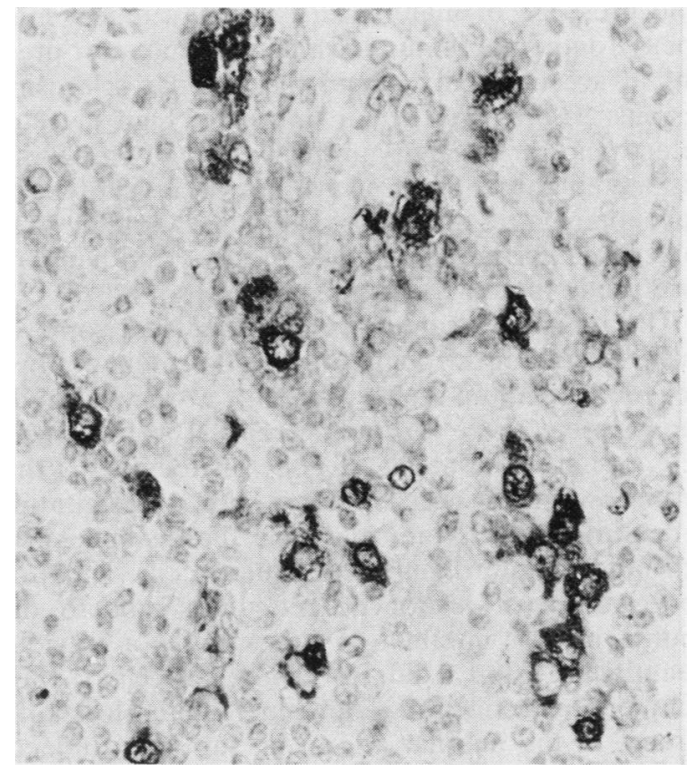

Fig. 3 Nodular sclerosing Hodgkin's disease at higher magnification than Fig. 2. Numerous cells positive for S-100 protein are seen. Primary antibody

peroxidase-antiperoxidase method for $S-100$ protein. Haemalum counterstain. $\times 550$.

generally shown a high percentage of $\mathrm{T}$ lymphocytes, but these studies are subject to considerable s.mpling errors and do not provide any information on the relation of different cell types.

In sections of lymph node a preponderance of B lymphocytes was observed in lymphocyte predominant Hodgkin's disease with a relative increase in $\mathrm{T}$ lymphocytes in mixed cellularity and nodular sclerosing subtypes. ${ }^{18}$ Analysis of T lymphocyte subsets in sections of Hodgkin's tissue ${ }^{19}$ showed that most of the $T$ lymphocytes have helper surface membrane markers, but in some cases ${ }^{20}$ the suppressor lymphocytes are numerically increased, although still outnumbered by helper $\mathrm{T}$ lymphocytes.

Reed-Sternberg cells are shown to be almost exclusively surrounded by helper $\mathrm{T}$ lymphocytes, ${ }^{19}$ suggesting that the lymphocytes in Hodgkin's disease do not represent a conventional cytotoxic reaction against the Reed-Sternberg cell. This relation between helper $T$ lymphocytes and Reed-Sternberg 
cells is similar to that observed with the interdigitating reticulum cells and has led to speculation that the Reed-Sternberg cell is derived from an antigen presenting reticulum cell in the areas of lymphoid tissue dependent on $\mathrm{T}$ lymphocytes.

The current findings of increased numbers of interdigitating reticulum cells in nodular sclerosing Hodgkin's disease, greater than those found in the reactive follicular hyperplasia, compared with the other three Rye subtypes are striking and consistent. The presence of many such cells may reflect microenvironmental features which are unique or present in accentuated form in the nodular sclerosing lesions. There may be an unusually high level of interchange and activity in this variety of Hodgkin's disease and other studies have shown this subtype to have many more mast cells ${ }^{5}$ and blood vessels ${ }^{21}$ than mixed cellularity, lymphocyte disease, and lymphocyte predominant Hodgkin's disease.

The possibility cannot be excluded that some of the cells staining strongly for S-100 protein are histiocytic reticulum cells. Indeed, a recent study showed that there is staining for $\mathrm{S}-100$ protein in cells assigned the name " $\mathrm{T}$ zone histiocytes" 22 ; this term however, is used on a par with interdigitating reticulum cells, as the cells have the histochemical attributes of interdigitating reticulum cells. Thus any contribution of histiocytic reticulum cells to the counts must be minimal, as for example, a previous quantitative study did not show especially high numbers of histiocytic reticulum cells in Hodgkin's disease in the nodular sclerosing subtype. ${ }^{3}$ Indeed, in the lymphocyte depletion variety, where cells containing S-100 protein are sparse, histiocytic reticulum cells are plentiful. ${ }^{3}$

We thank Mrs Ruth Fry for typing the manuscript and Mrs Pamela Jackson for graphics. The research was financially supported by a generous grant from the Research Committee of the West Midlands Regional Health Authority and the Leukaemia Research Fund. Computer programming was kindly carried out by $\mathrm{Mr} \mathrm{H}$ Sanders.

\section{References}

' Takahashi K, Yamaguchi H, Ishizechi J, Nakajima T, Nakazato J. Immunohistochemical and immunoelectron microscopic localisation of S-100 protein in the interdigitating reticulum cells of the human lymph node. Virchows Arch (Cell Pathol) 1981;37:125-35.

${ }^{2}$ Cocchia D, Michetti F, Donato R. Immunochemical and immunocytochemical localization of S-100 antigen in normal human skin. Nature 1981;294:85-7.

${ }^{3}$ Crocker J, Jones EL, Curran RC. A quantitative study of alphanaphthyl acetate esterase-positive cells in Hodgkin's disease. J Clin Pathol 1982;35: 1301-6.

${ }^{4}$ Fuggle WJ, Crocker J, Smith PJ. A quantitative study of eosinophil polymorphs in Hodgkin's disease. J Clin Pathol 1984;37:267-71.

${ }^{5}$ Crocker J, Smith PJ. A quantitative study of mast cells in Hodgkin's disease. J Clin Pathol 1984;37:519-22.

- Crocker J, Burnett D, Jones EL. Immunohistochemical demonstration of Cathepsin B in the macrophages of benign and malignant lymphoid tissues. J Pathol 1984;142:87-94.

${ }^{7}$ Lennert K. Malignant lymphomas other than Hodgkin's disease. Berlin: Springer-Verlag, 1978.

${ }^{8}$ Crocker J. The enzyme histochemistry of lymphomas. MD Thesis, University of Cambridge, 1983.

- Dukor P, Bianco C, Nussenzweig V. Tissue localization of lymphocytes bearing a membrane receptor for antigen-antibody complement complexes. Proc Natl Acad Sci USA 1970; 67:991-7.

${ }^{10}$ Moore BW. A soluble protein characteristic of the nervous system. Biochem Biophys Res Commun 1965;19:739-44.

"Nakajima T, Watanabe S, Sato Y, Shimosato Y, Motoi M, Lennert K. S-100 protein in Langerhans' cells, interdigitating reticulum cells and histiocytosis cells. Gann 1982;73:429-32.

${ }_{12}$ Lauriola L, Michetti F, Stolf VM, Tallini G, Cocchia D. Detection by $\mathrm{S}-100$ immunolabelling of interdigitating reticulum cells in human thymomas. Virchow Arch (Cell Path) 1984; 450: $187-95$.

${ }^{13}$ Balfour BM, Drexhage HA, Kamperdijk EWA, Hoefsmit ECM. Antigen-presenting cells, including Langerhans' cells, veiled cells and interdigitating cells. Ciba Found Symp 1981; 84:281-301.

${ }_{14}$ Poppema S, Bhan AK, Reinherz EL, McCluskey RT, Schlossman SF. Distribution of $T$ cell subsets in human lymph nodes. J Exp Med 1981;153:30-41.

is Payne SV, Newell DG, Jones DB, Wright DH. The Reef Sternberg cell/ymphocyte interaction. Ultrastructure an characteristics of binding. Am J Pathol 1980;100:7-24.

${ }^{16}$ Aisenberg AC, Wilkes BM. Lymph node T cells in Hodgkin? disease: analysis of suspensions with monoclonal antibody and rosetting techniques. Blood 1982;59:552-7.

${ }_{17}$ Dorreen MS, Habeshaw JA, Wrigley PFM, Lister TA. Distribution of T-lymphocyte subsets in Hodgkin's disease. Characterised by monoclonal antibodies. $\mathrm{Br} J$ Cancer 1982;45:491-9.

18 Poppema S, Elema JD, Halie MR. The localization of Hodgkin's disease in lymph nodes. A study with immunohistological, enzyme histochemical and rosetting techniques on frozen sections. Int J Cancer 1979; 24:532-40.

${ }^{19}$ Poppema S, Bhan AK, Reinherz EL, Posner MR, Schlossman SF. In situ immunologic characterization of cellular constituents in lymph nodes and spleens involved by Hodgkin's disease. Blood 1982;59:226-32.

${ }^{20}$ Martin JME, Warnke RA. A quantitative comparison of T-cell subsets in Hodgkin's disease and reactive hyperplasia. Cancer 1984;53:2450-5.

${ }^{21}$ Crocker J, Smith PJ. Immunohistochemical localisation of factor VIII-related antigen in Hodgkin's disease. J Clin Pathol 1984;37:37-44.

${ }_{22}$ Watanabe S, Shimosato Y, Nakajima T. Proliferative disorders of histiocytes. In: Malignant lymphomas. Pathology annual monograph. Norwalk, Connecticut: Appleton-Century-Crofts, $\mathrm{N}$ 1983:65-108.

Requests for reprints to: Dr J Crocker, Department of 6 Histopathology, East Birmingham Hospital, Bordesley $\bar{\complement}$ Green East, Birmingham B9 5ST, England. 